\title{
Trading off: the ecological effects of dam removal
}

\author{
Emily H Stanley $^{1}$ and Martin W Doyle ${ }^{2}$
}

Dam removal is gaining credibility as a viable management option for dams that have deteriorated physically and are no longer economically practical. However, the decision to remove or repair a dam is often contentious and emotionally charged. Part of the acrimony arises from our limited scientific knowledge of the effects of dam removal. We believe that the ecological consequences are best understood by viewing the removal process as a disturbance. Ecological outcomes will include changes that are both environmentally costly, such as invasion of exotic species, and environmentally beneficial, such as increasing access to spawning habitats for migratory fish. It has also become apparent that the wholesale aging of the US dam infrastructure will make dam removal even more common in the future. The challenge ahead is to better understand and manage the consequences of these removals.

Front Ecol Environ 2003; 1(1): 15-22

$\mathrm{T}$ wo phenomena emerged on the water management scene in the latter half of the 20th century. First, the supply of fresh water needed to sustain human populations became a major global concern (Postel 1997), bringing into focus questions about how best to manage this essential resource for present and future generations. Second, the world witnessed an unprecedented increase in the construction of large dams. At the end of World War II, there were approximately 5000 dams over $15 \mathrm{~m}$ high worldwide. By 1999, there were over 45000 such structures, with a total estimated price tag of $\$ 2$ trillion (WCD 2001).

The increasing severity and extent of water shortages, despite dam building, raised the question of just how effective dams have been for the development and management of water and energy resources - a question taken on by the World Commission on Dams (WCD) in 1997. Four years later, the WCD concluded that, although dams have significantly contributed to human development and the benefits derived from dams have been considerable, the economic, social, and environmental price has been unacceptably high (WCD 2001). Furthermore, the

In a nutshell:
- Dam removal is an increasingly common way of dealing with
aging and uneconomical dams
- The resulting loss of reservoir habitat and movement of sedi-
ments can cause ecological and environmental change.
- Some of these changes could be beneficial - eg increased fish
migration - but others may be costly - eg increased mortality
among downstream aquatic communities

${ }^{1}$ University of Wisconsin, Center for Limnology, $680 \mathrm{~N}$ Park St, Madison, WI 53706 (ehstanley@wisc.edu); ${ }^{2}$ Department of Geography, University of North Carolina, Chapel Hill, NC 27599. 3220 (mwdoyle@email.unc.edu)
Commission noted the irony that, while most people approach important purchases with a healthy skepticism and a consideration of the alternatives before spending money, dams are being built and assigned value without such scrutiny. Resource-management groups have therefore begun to consider ways to reduce the cost of dams. It is in this context that a third trend in water management emerged at the end of the century, namely the removal of dams for which the costs seem to far outweigh the benefits.

To date, the debate over, and occurrence of, dam removal has been most vigorous in the US, where over 500 dams have been removed in the past two decades, in comparison to less than ten reported removals worldwide (WCD 2001; IRN 2002). We review the current understanding of the environmental effects of dam removal, drawing on the US experience. Our goal is to highlight the major ecological changes, in order to emphasize that this action is not an environmental panacea, but instead is best seen in terms of trade-offs. Most examples describe the removal of small dams (those that create reservoirs with a storage of 100 acre-ft [123000 m³ or less; Heinz Center 2002), because few structures larger than $20 \mathrm{~m}$ have been removed (Poff and Hart 2002). We rely heavily on the accumulated knowledge and experience from the state of Wisconsin, where over 50 dams have been removed since 1967 (WDNR 2002), giving it one of the greatest legacies of dam removal in the country (Born et al. 1998). Despite the geographic and size limitations, the issues raised should be relevant to the removal of both large and small dams throughout the world.

\section{The ecological context}

By blocking flow, dams raise water heights, inundate surrounding terrestrial habitats, and slow the velocity of flowing water in rivers. Sediments and debris that would 


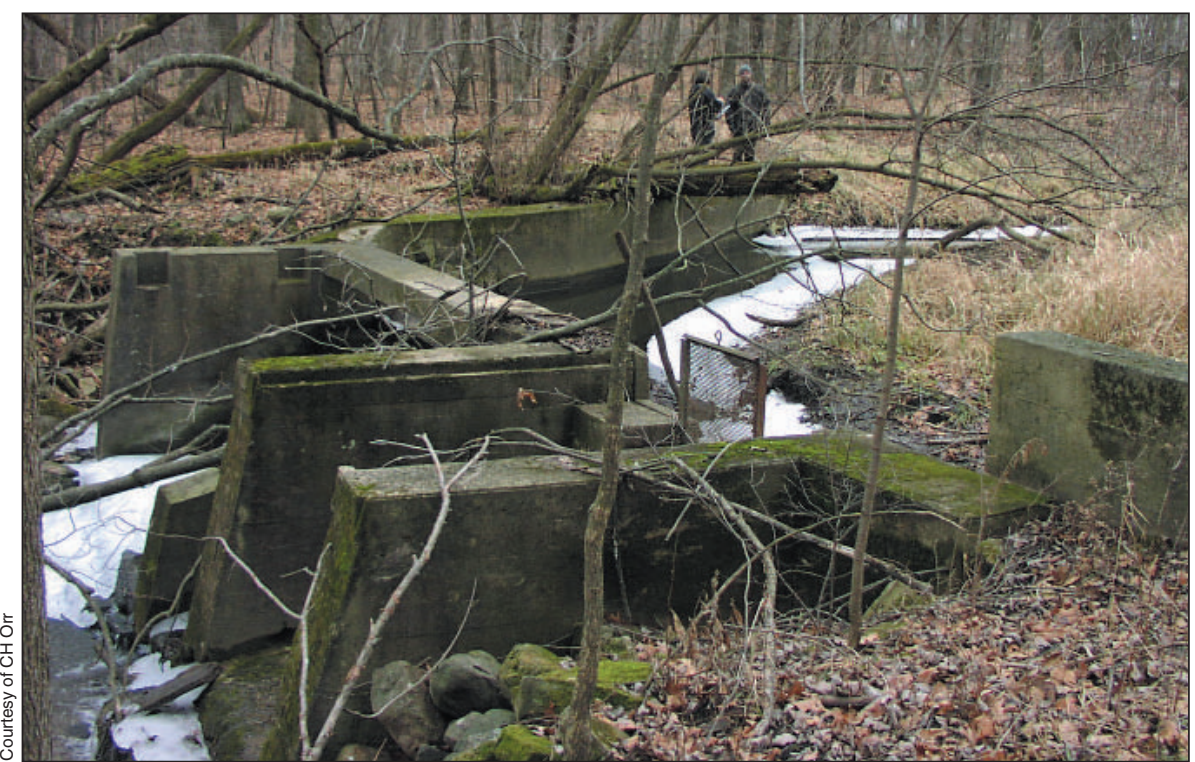

Figure 1. The Boulder Creek dam, Wisconsin was constructed during the 1930s as part of a fish hatchery operation. The impoundment is now completely filled with sediments and has been colonized by grasses and weeds. The structurally compromised dam is scheduled for removal in 2003.

normally remain suspended in the water column and continue to move downstream instead settle out and collect within reservoirs. Accumulation is often so substantial that some reservoirs shift from their original function of water storage to becoming sediment storage devices (Figure 1). The filling process greatly decreases the functional lifespan of a reservoir (Palmieri et al. 2001) and increases the likelihood of eventual dam failure (Evans et al. 2000).

When a dam is removed, the river begins to recreate a

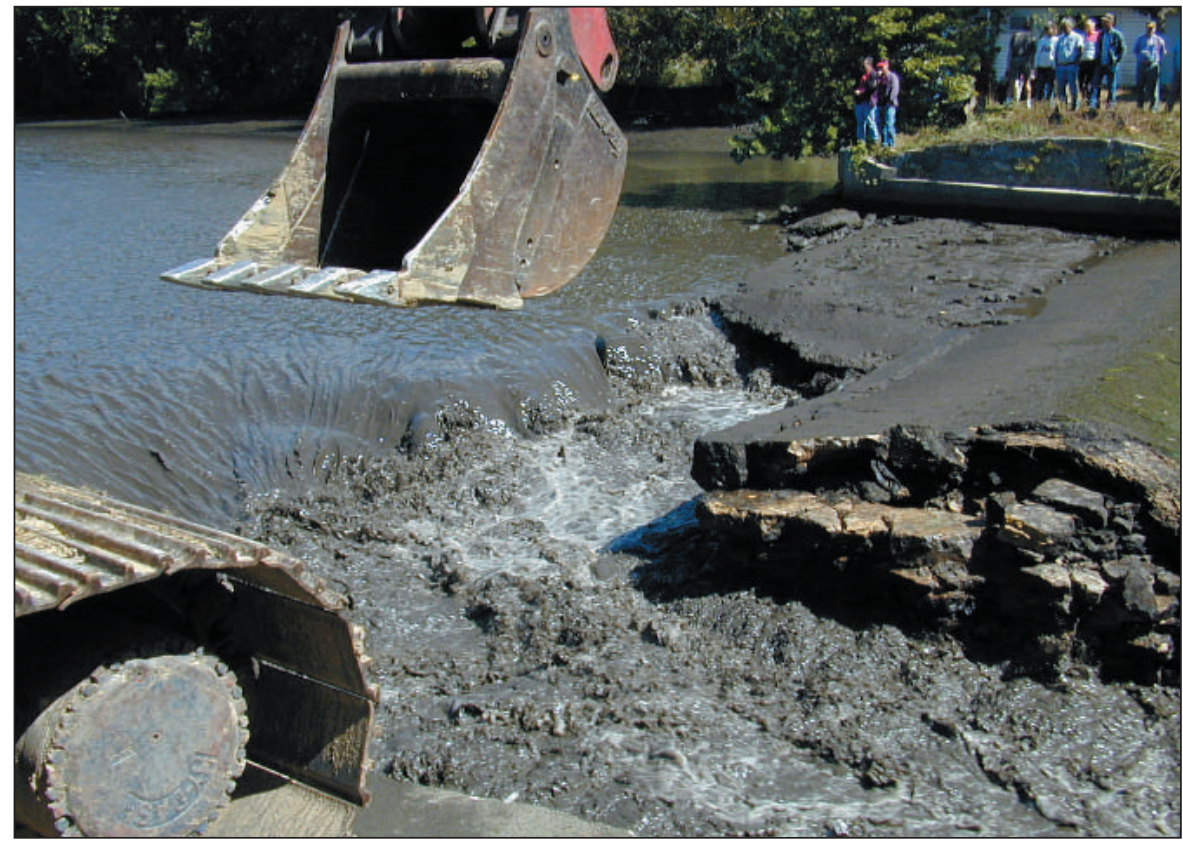

Figure 2. A torrent of muddy brown water is released following the breaching of the Rockdale Dam, Wisconsin. Downstream concentrations of suspended sediment increased by three orders of magnitude over a 2-hour period and remained elevated over the next 3 days. channel by cutting into the mound of accumulated sediment and transporting it downstream (Figure 2). Exposed sediment lateral to the forming channel dries and, over time, becomes more physically stable, giving rise to a new floodplain. Let us consider the ecological consequences of dam removal with respect to these processes of sediment exposure, erosion, and redistribution, as well as barrier removal and reestablishment of uninterrupted flow.

\section{Changing of the guard}

In the simplest sense, dam removal converts a reservoir into river and riparian habitats. Riverine species should therefore increase at the expense of reservoir taxa. Dewatering and elimination of the reservoir results in dramatic changes soon after dam removal (Figure 3 ), as extensive areas of featureless sediment and previously submerged structures come into view. Organisms present in the reservoir prior to removal may be washed downstream or stranded during surface water drawdown (Figure 4). Mortality rates of virtually all reservoir populations, except fish, will be extremely high and can be expected to approach $100 \%$ if dewatering is rapid.

For some groups of organisms, replacement of reservoir assemblages by more typical riverine taxa can occur relatively quickly after the dam is taken out. For example, fish and macroinvertebrates adapted to slow-moving water and silty sediments gave way to riverine taxa within a year of removal of two separate dams in Wisconsin (Kanehl et al. 1997; Stanley et al. 2002). Much to the delight of local anglers, changes in the fish community included declines in common carp (Cyprinus carpio) and increases in smallmouth bass (Micropterus dolomieu) and darters (Etheostoma and Percina spp). In both studies, the recovery of riverine taxa reflected both recolonization of individuals that had previously resided upstream or downstream from the dam and successful reproduction within this newly created habitat.

Although quantitative studies of plant communities have yet to be completed, vegetation shifts follow- 
ing dam removal appear to mirror those of their aquatic counterparts, although these changes play out over several years or decades. After removal, riparian vegetation along reservoir margins may eventually die due to the water table decline (Shafroth et al. 2002). This mortality is accompanied by the prompt colonization of newly exposed sediments (Figure 4). We have observed former reservoir areas "greening up" during the first growing season after removal at several sites in Wisconsin. The first colonists are usually fast-growing forbs and grasses, followed later by longerlived species, including riparian trees. Because taking out dams creates "new" habitat, and because sed-

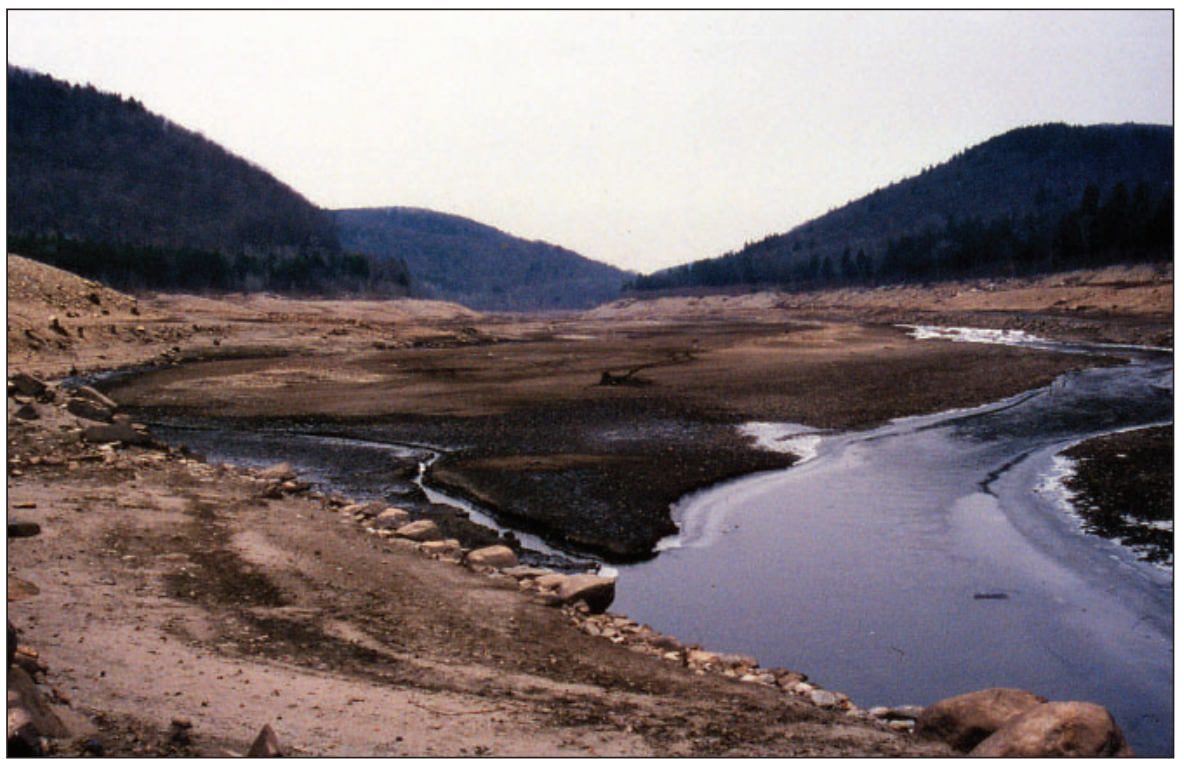

Figure 3. The blank palette: lowering of the water level often exposes vast areas of reservoir sediment. iments are amenable to plant

growth, dam removal may be a valuable tool for riparian restoration (Shafroth et al. 2002). However, widely available and often nutrient-rich sediment also represents prime habitat for invasion of weedy and exotic species that are generally considered undesirable (Shafroth et al. 2002). Observations of plant communities at several Wisconsin dam-removal sites show that species such as stinging nettle (Urtica diocia) and the invasive reed canary grass (Phalaris arundinaceae) are often abundant (CH Orr pers comm; Figure 5).

\section{Reforming the river}

The chief concern of the agencies responsible for removing a dam is the management of sediments within the reservoir (Shuman 1995; TCGRDHF 1997). Dam removal can result in decades of accumulated material being released downstream in a rapid and catastrophic fashion. In very small impoundments, or those with limited accumulation, sediments can be flushed out relatively rapidly (Stanley et al. 2002). In contrast, the development of new channels in larger reservoirs is a more prolonged and dynamic process that may sustain downstream sediment export for months or even years (Simons and Simons 1991; Doyle et al. in press a). Unfortunately, despite awareness of the importance of sediment management, there is remarkable uncertainty regarding patterns and rates of sediment transport following dam removal (Rathburn and Wohl 2001; Pizzuto 2002).

Common patterns of channel formation following reservoir drawdowns, or dam removals or failures, include an initial stage of vertical erosion in which deep, narrow (incised) channels form, followed by a period of lateral erosion in which steep banks fail, causing channels to widen and migrate laterally (Evans et al. 2000; Doyle et al. in press b). Thus, formerly impounded river reaches can become shifting and unpredictable mosaics of sediment and water as these formation and adjustment processes unfold. During an experimental drawdown of the Lake Mills Reservoir on the Elwha River, WA, in preparation for its removal in 2006, water levels were dropped by approximately $5.5 \mathrm{~m}$ to study channel formation and the sediment transport processes that will occur when the dam is eventually breached. Vertical incision and subsequent widening were observed in the exposed sediments and newly formed channels migrated across the sediment surface by as much as $24 \mathrm{~m}$ per day (Childers et al. 2000). The dramatic shifting and reconfiguring of channels provided only a hint of things to come in the Elwha, because the drawdown exper-

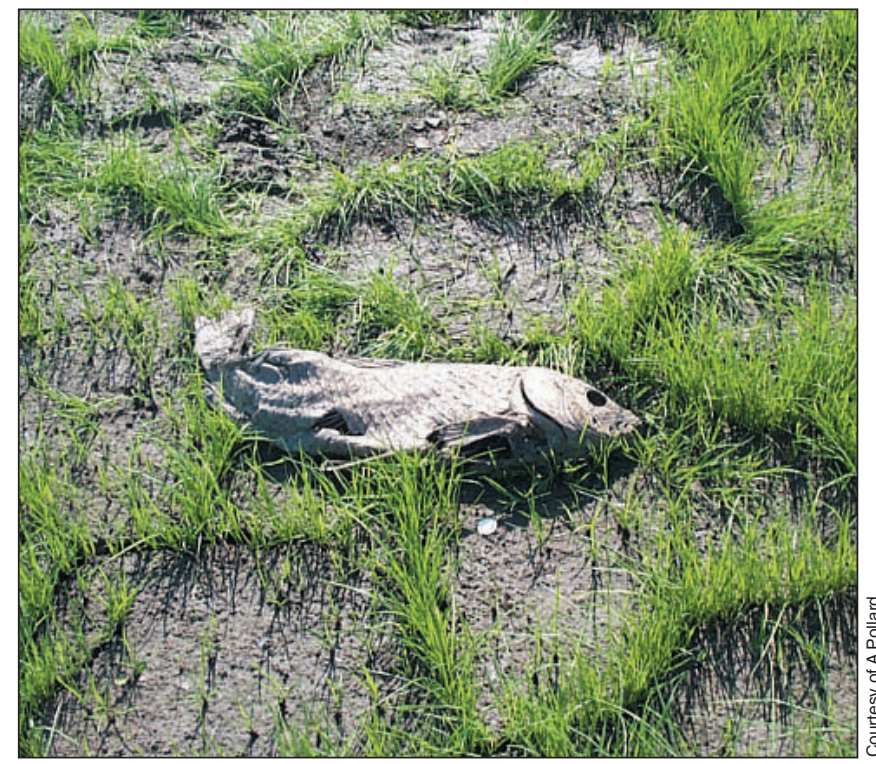

Figure 4. Out with the old, in with the new. Former reservoir residents such as carp suffer high mortality rates following dam removal, but newly exposed sediments provide an amenable substrate for plant colonization. 


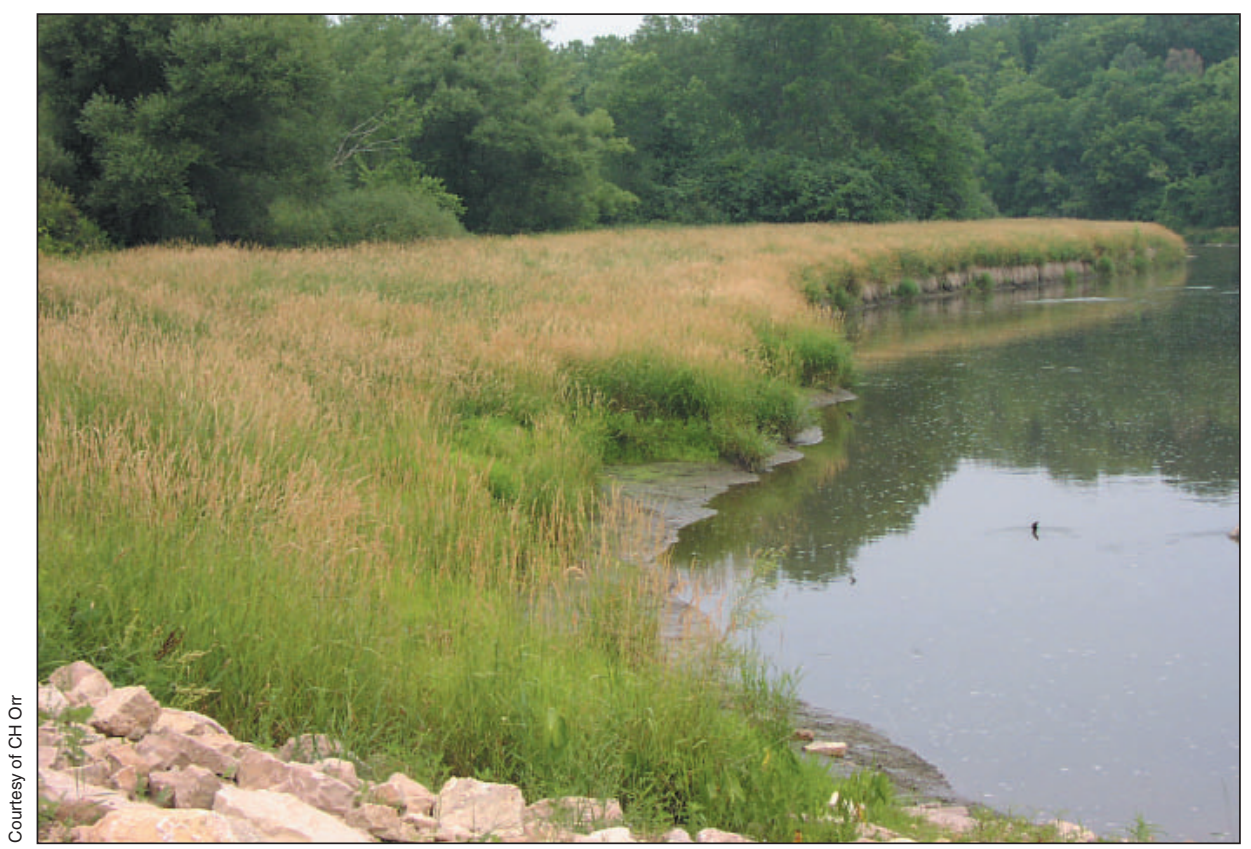

Figure 5. Exposed reservoir sediments are well suited for invasion by exotic species such as reed canary grass (Phalaris arundinaceae). Following removal of the Oak Street Dam, Wisconsin, exposed sediments were seeded with mixtures of native prairie plants. Two years later, reed canary grass has taken over and grows in large stands on former reservoir sediments. (it is done routinely as part of the removal process in Wisconsin), deposits of contaminated sediment may be localized and difficult to detect. For example, 2980 $\mathrm{m}^{3}$ of sediments contaminated with polyaromatic hydrocarbons (PAHs) were discovered at one Wisconsin site, not by sediment testing but during the collection of invertebrate samples prior to removal (Stanley et al. 2002).

In many Midwestern states, reservoir sediments frequently contain a similar chemical legacy in the form of nutrient-rich particles derived from past and present agricultural activity (Stanley and Doyle 2002). Removal may then reintroduce nutrients that had been stored for decades, causing enrichment of downstream rivers, lakes, and even coastal areas. In support of this prediction, Gray and Ward (1982) found that the iment represented only $20 \%$ of the elevation change that will occur with full dam removal.

\section{The sediment legacy}

As sediments accumulate over the years, they record a history of the reservoir and the surrounding watershed (Evans et al. 2000). Problems can arise when channel formation processes expose and transport material previously stored behind the dam. The removal of the Fort Edwards Dam on the Hudson River in New York State, perhaps one of the most infamous dam-removal cases, demonstrates this. Following partial removal of the Fort Edwards Dam in 1973, large quantities of oils and sediments rich in polychlorinated biphenyls (PCBs) were released into the river, requiring a costly cleanup effort (Shuman 1995). The sediment moved into the river, where it restricted flow and blocked the navigation channel and access to adjacent riverside businesses. The altered flow created an additional health hazard when sewage, discharged into the river by the town of Fort Edwards, could not be conveyed downstream (Heinz Center 2002). A second wave of contaminated sediments was mobilized in 1991, when the remaining structure was removed. The following year, average $\mathrm{PCB}$ concentrations in striped bass had doubled (HRF 2002).

Many US dams were originally built for industrial purposes, or to act as focal points for urban growth. This means that sediment contamination may not be unusual in these older reservoirs, adding additional costs and urgency to a removal process (Lenhart 2003). Although sediment testing is often performed prior to dam removals flushing of sediments from the Guernsey Reservoir on the North Platte River caused a sixfold increase in downstream phosphorus concentrations and stimulated the growth of large filamentous green algal mats. Similarly, when the Capilano Reservoir in British Columbia was drawn down for structural improvements to the dam, ammonium in the sediments was released into the water column, increasing concentrations by two orders of magnitude over the 4-month period when the water level was being lowered (Perrin et al. 2000). Thus, there is the very real possibility that by adding to already elevated nutrient concentrations in rivers, dam removal will be at odds with nutrient management strategies in some parts of the US (Stanley and Doyle 2002).

\section{- Looking downstream}

Sediments mobilized by channel formation processes in tle on channel beds and banks (Figure 6). The amount of suspended sediment increases greatly during and after drawdown and removal, often by three to five orders of magnitude (Childers et al. 2000; Doyle et al. in press a), and conditions of high turbidity may persist for months (Perrin et al. 2000). Because reservoirs trap fine particles, released material can remain suspended in the water column for several kilometers (Gray and Ward 1982). The ecological impact of suspended sediment specifically released by dam removal has not yet been considered, but many negative effects of both pulsed and sustained inputs of sediments to stream biota are well documented (Waters 1995).

Studies of both accidental and intentional sediment the reservoir are transported downstream, where they set- 
releases from reservoirs have described a range of physical and ecological changes downstream from dams. Decreased streambed particle size, sediment deposition on lateral and in-channel bars, and filling of a downstream impoundment followed three small dam removals in Wisconsin (Stanley et al. 2002; Doyle et al. in press a). However, downstream sediment deposition does not always produce detectable changes in algal or invertebrate communities (Stanley et al. 2002, Bushaw-Newton et al. in press), either because the magnitude of impact is minimal or because the rate of recovery is rapid. In contrast, sediments released from a Colorado reservoir filled pools and clogged the interstitial spaces between coarse sediments in the channel bed up to $12 \mathrm{~km}$ below the reservoir (Wohl and Cenderelli 2000) and killed over 4000 fish (Rathburn and Wohl 2001). Declines in densities and shifts in species composition of macroinvertebrate communities were also observed (Zuellig et al. 2002). Similar patterns of fish and invertebrate mortality were reported by Doeg and Koehn (1994), following the desilting of a small reservoir in Australia. A second reduction in fish and invertebrate numbers also occurred several months later, demonstrating that the downstream effects of sediment releases may be prolonged as the material works its way through the system.
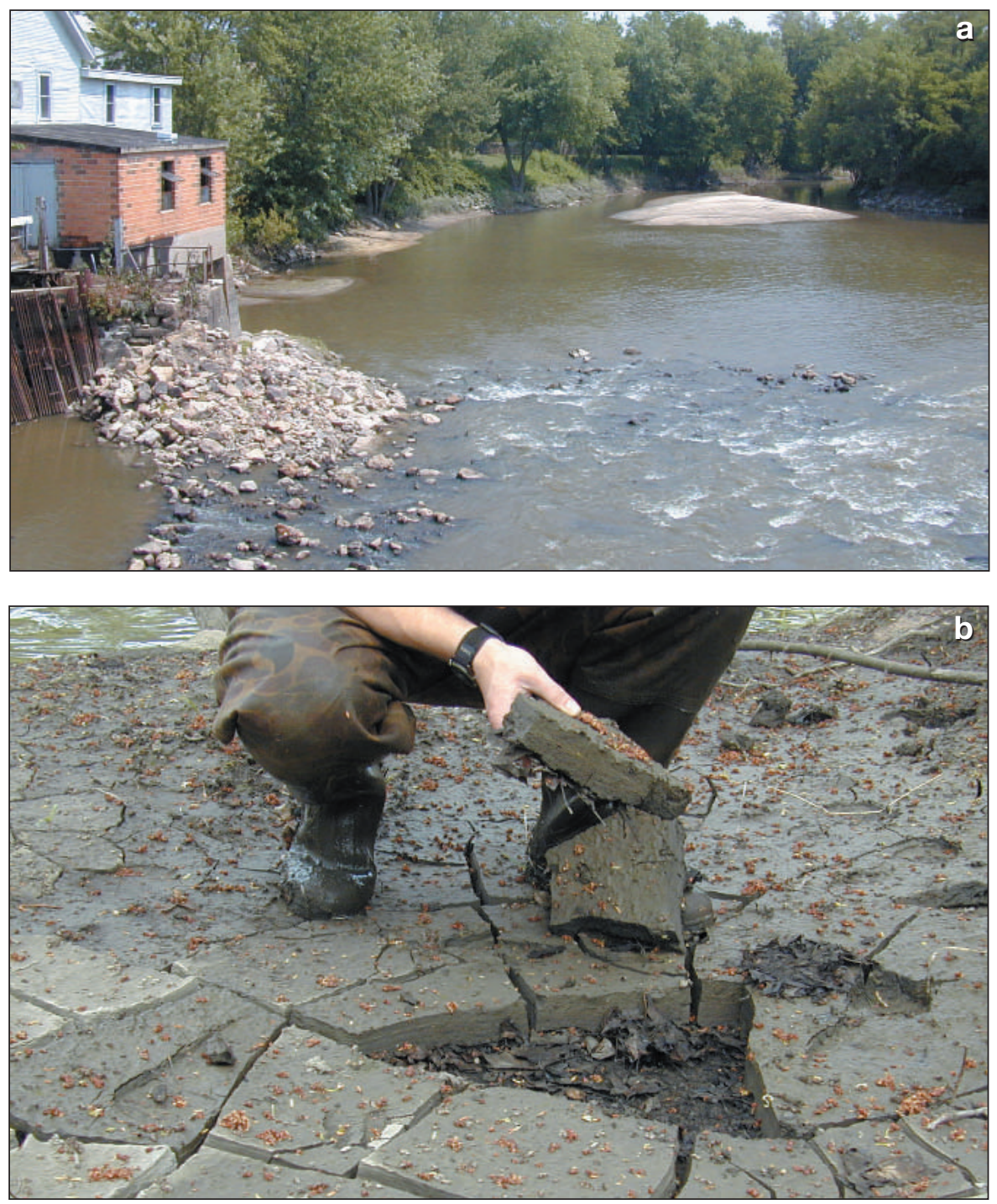

Figure 6. Once released from the reservoir, sediments travel downstream and settle out. (a) A large sand bar formed approximately $50 \mathrm{~m}$ below the former dam and mill site (building on the left) shortly after the removal of the LaValle Dam, on the Baraboo River, Wisconsin. (b) A layer of fine sediments blankets the banks of Koshkonong Creek at a site $4 \mathrm{~km}$ below the reservoir after removal of the Rockdale Dam, Wisconsin.

Ultimately, the effects of reservoir-derived deposition will depend on how sediments move into and through downstream reaches and the ecological attributes of the resident biota. Organisms with short generation times are able to recover quickly from sediment releases (Gray and Ward 1983), but long-lived species, especially sessile organisms, are more vulnerable. For instance, we have observed that deposition of fine sediments caused localized mortality of freshwater mussels following a dam removal in southern Wisconsin, a worrisome observation given the precarious conservation status of this group (Master 1990).

\section{Overcoming hurdles}

One of the most widely publicized ecological aspects of dam removal is the elimination of barriers to fish migration. As yet, we are unaware of published articles that have documented changes in population sizes of migratory species following a removal, but fish moving into formerly inaccessible reaches have been reported for several rivers in the US (American Rivers et al. 1999) and France (ERN 2002). Following the removal of the Edwards Dam in Maine's Kennebeck River, striped bass, alewife, shad, Atlantic salmon, and sturgeon all traveled past the former dam site (American Rivers 2002).

Despite these apparent successes, removal of dams as a means of restoring fish species that migrate up rivers to breed has been an area of contention in dam and fisheries management. In the US, this debate is well illustrated by the dams on the Lower Snake River, WA. While widespread and dramatic declines in salmon runs in the Pacific Northwest are clearly recognized, the best course of action for reversing these trends is less apparent. Dam removal alone will not restore native fish runs 
(NRC 1996) and may even create additional problems for the fishery. Indeed, the removal of the Snake River dams may do little to increase spring and summer Chinook salmon (Kareiva et al. 2000, but see Dambacher et al. 2001). In Oregon, the planned removal of the Marmot Dam on the Sandy River will give wild salmon access to long stretches of spawning habitat. However, this structure currently acts as a filter point for separating hatchery-raised from wild individuals and thus helps maintain the genetic integrity of the latter (ODFW 2000). Removal of the Marmot Dam, originally scheduled to occur in 2000, is now targeted for 2007. This will allow for the resolution of conflicting stakeholder issues, including the costs and benefits to salmon.

\section{Conclusions}

In this brief overview, the consequences of dam removal have been considered in terms of responses to physical changes caused by dewatering a reservoir and removing the dam structure, not as equal and opposite reactions to the effects of dams on rivers. There are two reasons for this perspective. First, dam removal occurs in circumstances far different from dam construction, since not only do dams change rivers over their lifetimes, but the area surrounding the dam also changes. Rather than erasing past environmental legacies, dam removal creates a new ecological template upon which subsequent physical, chemical, and biological processes will be played out. Second, regardless of the long-term outcomes, removing a dam is not a gentle process. It disrupts and reconfigures the existing physical environment and eliminates an entire ecosystem. Dam removal should therefore be considered a disturbance in the strict ecological sense of a "discrete event in time that disrupts ecosystem, community, or population structure, and changes resources, substrate availability, or the physical environment" (White and Pickett 1985). Also, because it is a disturbance, we should expect substantial changes in many ecological variables, including the loss of resident flora and fauna and the disruption of ecosystem processes, at least in the short term. Ecologists face key questions regarding the mechanisms and rates of change after the removal, and the longer-term trajectories of these changes.

Dam removal must be seen as a trade-off. Some of the results may be considered beneficial, while others are costly. Some management goals will be achieved quickly and easily, but others will be more elusive. It is unrealistic to assume that removal will simply and rapidly reverse the suite of conditions created by a dam's construction, and it may be foolhardy to minimize or ignore the fact that some outcomes are likely to represent environmental setbacks.

Ecological responses to dam removal and potential trade-offs will depend strongly on context. The specific nature of the trade-offs will depend on the size and configuration of the dam and reservoir, local legacies, and the composition of the resident biota. Some simple and preliminary examples of regional trade-offs that have been documented to date include anadromous fish migration balanced against water use in the western US (Smith et al. 2000; Lenhart 2003), nutrient management versus fish habitat improvement in Midwestern states (Kanehl et al. 1997; Stanley and Doyle 2002), and ecosystem restoration versus increased flooding due to the loss of ice retention in the northeast (White and Moore 2002).

Finally, one must consider the current status of the science of dam removal. To date, management actions have led scientific research (Grant 2001; Babbitt 2002) and several important consequences of dam removal have not yet received any research attention. Virtually all the examples we cited involved relatively small dams with little or no effect on the river's flow regime or downstream water quality prior to their removal. Yet larger dams with substantial water storage capacity alter downstream flow regimes and water quality. How river ecosystems respond to reestablishment of a more natural flow regime remains an important area for future research, particularly with respect to resolving conflicting water needs for irrigation and sustainability of aquatic communities.

Finally, we suggest that endorsements for or against dam removal are often irrelevant. Dam management is unusual because the "no action" alternative may, in the end, be the most costly choice. It perpetuates the deleterious effects of dams while increasing the likelihood of uncontrolled release of water and sediments by dam failure. Reliable data are not available to determine if failures are becoming more prevalent, but more than 400 dams failed in the US between 1985 and 1994 (Graham 1998). Similarly, in a recent survey of 10000 floodcontrol dams, over 2200 sites were in need of maintenance, at an estimated cost of $\$ 543$ million (NRCS 2000). Past dam failures have not only caused serious environmental damage, but also devastating losses of property and human lives (Graham 1998; Cenderelli 2000). Deteriorating structures must eventually be removed, repaired, or replaced to avoid these outcomes. The cost of repairing structural deterioration, particularly for dams that generate limited revenues, is likely to make dam removal the best course of action in many, but certainly not all, cases.

The debate is often separated into two parts: the removal of small dams for economic and safety reasons, and the removal of large dams, where discussions center on conflicting environmental and economic considerations (eg Hart et al. 2002; Heinz Center 2002). With time, this distinction will become increasingly blurred. Large dams will age and deteriorate just as older, smaller dams have. By 2020, the vast majority of large US dams will have reached or passed their intended life expectancy (Bednarek 2001). Many European dams were built in the first half of the 20th century and are now also reaching the end of their functional lifetime. According to one conservative estimate, in the next decade over 10000 structures 
in western and northern Europe are due for relicensing (which occurs every 40-60 years) (Epple 2002).

Financial and temporal realities dictate that, regardless of trade-offs, dam removal will become increasingly common. Indeed, this trend is already underway. In the US, fewer than 20 dam removals per decade were reported in the 1960s and 1970s, approximately 100 dams were removed in the 1980s, and 160 in the 1990s (Doyle et al. 2000; Poff and Hart 2002). In 2002 alone, American Rivers (2002) reports that 63 dams will be taken out in the US. Furthermore, although the vast majority of intentional removals have occurred in the US, interest in dam removal is not limited to this country. France and Norway have also undertaken removals for restoration purposes, and discussions regarding decommissioning are becoming increasingly common worldwide (IRN 2002). The World Commission on Dams report is particularly important in this context, as it concluded that decommissioning should always be considered as an option when operation and management of a dam are being evaluated.

While the costs of dam removal will never be completely eliminated, some expensive outcomes should be controllable through supplementary management actions, or by carefully choosing the timing and the means by which the dam is removed. The combination of management action and scientific ignorance regarding the consequences of dam removal is ironically reminiscent of the era of dam building in the US (Babbitt 2002), and suggests that we are in danger of making decisions with costly long-term effects. Because dam removal cannot be avoided, the challenge that lies ahead is to understand the relationship between the act of removal and ecological responses to this action.

\section{Acknowledgements}

This article covers research supported by the Bradley Fund for the Environment, a Horton Grant to M. Doyle from the American Geophysical Union, and NSF grant DEB-0108619 to E. Stanley. We thank C Bromley, A Pollard, C Orr, and G Stewart for use of photographs, G Stewart for additional support materials, and CH Orr, JF Kitchell and DD Hart for their thoughtful comments.

\section{References}

American Rivers. 2002. Edwards Dam case study. www.amrivers.org/damremovaltoolkit/edwardsdam.htm, viewed 28 July 2002.

American Rivers, Friends of the Earth, Trout Unlimited. 1999. Dam removal success stories: restoring rivers through selective removal of dams that don't make sense. Washington, DC: American Rivers, Friends of the Earth, Trout Unlimited.

Babbitt B. 2002. What goes up, may come down. BioScience 52: 656-58.

Bednarek AT. 2001. Undamming rivers: a review of the ecological impacts of dam removal. Environ Manage 27: 803-14.
Born SM, Genskow KD, Filbert TL, et al. 1998. Socioeconomic and institutional dimensions of dam removals: the Wisconsin experience. Environ Mgt 22: 359-70.

Bushaw-Newton KL, Hart DD, Pizzuto JE, et al. An integrative approach towards understanding ecological responses to dam removal: the Manatawny Creek study. J Am Wat Resour As. In press.

Cenderelli DA. 2000. Floods from natural and artificial dam failures. In: Wohl EE (Ed). Inland flood hazards. Cambridge, UK: Cambridge University Press.

Childers D, Kresch DL, Gustafson SA, et al. 2000. Hydrologic data collected during the 1994 Lake Mills drawdown experiment, Elwha River, Washington. Tacoma, WA: US Geological Survey. Water Resources Investigations Report 99-4215.

Dambacher JM, Rossignol PA, Li HW, and Emlen JM. 2001. Dam breaching and chinook salmon recovery. Science 291:939a.

Doeg TJ and Koehn JD. 1994. Effects of draining and desilting a small weir on downstream fish and macroinvertebrates. Regul River 9: 263-277.

Doyle MW, Stanley EH, and Harbor JM. Channel adjustments following two dam removals in Wisconsin. Wat Resour Res. In press [a].

Doyle MW, Stanley EH, and Harbor JM. Assessing probable channel response to dam removal using geomorphic analogies. J Am Wat Resour As. In press b.

Doyle MW, Stanley EH, Luebke MA, and Harbor JM. 2000. Dam removal: physical, biological, and societal considerations In: Hotchkiss RH and Glade N (Eds). Proceedings of the 2000 joint conference on water resources engineering and water resources planning and management. New York, NY: American Society of Civil Engineers.

Epple R. 2002. Dam decommissioning: French pilot experiences and the European context. www.rivernet.org/decom3_e.htm, viewed 20 October 2002.

Evans JE, Mackey SD, Gottgens JF, and Gill WM. 2000. Lessons from a dam failure. Ohio J Sci 100: 121-31.

Graham WJ. 1999. A procedure for estimating the loss of life caused by dam failure. Washington DC: US Department of Interior. Bureau of Reclamation Report DSO-99-06.

Grant G. 2001. Dam removal: panacea or Pandora for rivers? Hydrol Proc 15: 1531-32.

Gray LJ and Ward JV. 1982. Effects of sediment releases from a reservoir on stream macroinvertebrates. Hydrobiologia 96: 177-84.

Hart DD. Johnson TE, Bushaw-Newton KL, et al. 2002. Dam removal: challenges and opportunities for ecological research and river restoration. BioScience 52: 669-81.

Heinz Center. 2002. Dam removal: science and decision making. Washington DC: H.J. Heinz Center for Science, Economics and the Environment.

Hudson River Foundation (HRF). 2002. Harbor health/human health: An analysis of environmental indicators for the NY/NJ Harbor Estuary. www.hudsonriver.org, viewed 25 July 2002.

International Rivers Network (IRN). 2002. Reviving the world's rivers: the global view of dam removal. www.irn.org/revival/decom/brochure/rrpt1.html Viewed: 20 October, 2002.

Kanehl, PD, Lyons J, and Nelson JE. 1997. Changes in the habitat and fish community of the Milwaukee River, Wisconsin, following removal of the Woolen Mills Dam. N Am J Fish Manage 17: 387-400.

Kareiva P, Marvier M, and McClure M. 2000. Recovery and management options for spring/summer chinook salmon in the Columbia River Basin. Science 290: 977-79.

Lenhart CF. 2003. An assessment of NOAA community-based fish passage and dam removal projects. Coast Manage. 31: 77-96.

Master L. 1990. The imperiled status of North American aquatic animals. Biodivers Net News 3: 5-7.

National Research Council (NRC). 1996. Upstream: salmon and 
society in the Pacific Northwest. Washington DC: National Academy Press.

National Resources Conservation Service (NRCS). 2000 A report to Congress on aging watershed infrastructure. Washington DC: US Department of Agriculture, Natural Resources Conservation Service.

Oregon Department of Fish and Wildlife (ODFW). 2002. ODFW Commission to be briefed on Sandy River fish releases and basin plan revision in light of dam removal. www.dfw.state.or.us/public/NewsArc/2000News/January/02100 Onews.htm, viewed 29 June 2002.

Palmieri A, Shah F, and Dinar A. 2001. Economics of reservoir sedimentation and sustainable management of dams. J Environ Manage 61: 149-63.

Pejchar L and Warner K. 2001. A river might run through it again: criteria for consideration of dam removal and interim lessons from California. Environ Manage 28: 561-75.

Perrin, CJ, Ashley KI, and Larkin GA. 2000. Effects of drawdown on ammonium and iron concentrations in a coastal mountain reservoir. Water Qual Res J Can 35: 231-44.

Pizzuto J. 2002. Effects of dam removal on river form and process. BioScience 52: 683-91.

Poff NL and Hart DD. 2002. How dams vary and why it matters for the emerging science of dam removal. BioScience 52: 659-68.

Postel S. 1997. Last oasis: facing water scarcity. New York: WW Norton.

Rathburn SL and Wohl EE. 2001. One-dimensional sediment transport modeling of pool recovery along a mountain channel after a reservoir sediment release. Regul River 17: 251-73.

Shafroth PB, Friedman JM, Auble GT, et al. 2002. Potential responses of riparian vegetation to dam removal. BioScience 52: 703-12.

Shuman JR. 1995. Environmental considerations for assessing dam removal alternatives for river restoration. Regul River 11: 249-61.

Simons RK and Simons DB. 1991. Sediment problems associated with dam removal - Muskegon River, Michigan. In: Shane RM (Ed). Hydraulic engineering: proceedings of the national con- ference on hydraulic engineering. New York: American Society of Civil Engineers.

Smith LW, Dittmer E, Prevost M, and Burt DR. 2000. Breaching of a small irrigation dam in Oregon: a case history. $N$ Am J Fish Manage 20: 205-19.

Stanley EH and Doyle MW. 2002. A geomorphic perspective on nutrient retention following dam removal. BioScience 52: 693-701.

Stanley EH, Luebke MA, Doyle MW, and Marshall DW. 2002. Short-term changes in channel form and macroinvertebrate communities following low-head dam removal. J N Am Benthol Soc 21: 172-87.

Task Committee on Guidelines for Retirement of Dams and Hydroelectric Facilities (TCGRDHF). 1997. Guidelines for retirement of dams and hydroelectric facilities. New York: American Society of Civil Engineers.

Waters TF. 1995. Sediments in streams: sources, biological effects and controls. Bethesda, MD: American Fisheries Society.

White KD and Moore JN. 2002. Impacts of dam removal on riverine ice regime. J Cold Reg Eng 16: 2-16.

White PS and Pickett ST. 1985. Natural disturbance and patch dynamics: an introduction. In: Pickett ST and White PS (Eds). The ecology of natural disturbance and patch dynamics. New York: Academic Press.

Williams DT. 1977. Effects of dam removal: an approach to sedimentation. Davis, CA: Hydrologic Engineering Center.

Wisconsin Department of Natural Resources (WDNR). 2002. www.dnr.state.wi.us/org/water/wm/dsfm/dams/index.html, viewed 30 July 2002.

Wohl EE and Cenderelli DA. 2000. Sediment deposition and transport patterns following reservoir sediment release. Water Resour Res 36: 319-33.

World Commission on Dams (WCD). 2000. Dams and development: a new framework for decisions-making. London: Earthscan Publications.

Zuellig RE, Kondratieff BC, and Rhodes HA. 2002. Benthos recovery after an episodic sediment release into a Colorado Rocky Mountain river. West N Am Nat 62: 59-72. 